\title{
Mucoepidermoid Carcinoma in a Breast Affected by Burn Scars: Comprehensive Literature Review and Case Report
}

\author{
Murat Basbug $^{a} \quad$ Sami Akbulut $^{a} \quad$ Zulfu Arikanoglu ${ }^{a} \quad$ Nilgun Sogutcu $^{b}$ \\ Ugur Firat $^{c}$ Mehmet Kucukoner ${ }^{d}$ \\ aDepartment of Surgery, \\ ${ }^{b}$ Department of Pathology, Diyarbakir Education and Research Hospital, \\ 'Department of Pathology, \\ ${ }^{\mathrm{d}}$ Department of Medical Oncology, Dicle University Hospital, Faculty of Medicine, Diyarbakir, Turkey
}

\section{Keywords}

Mucoepidermoid carcinoma · Breast · Burn

\section{Summary}

Background: Mucoepidermoid carcinoma (MEC), which is primarily found in the salivary glands, is rarely seen in the breast. These tumors usually develop from squamous and mucus-secreting cells. Histological grading is an important prognostic factor. Case Report: We present herein a case of a 69-year-old female patient with a painful mass in the left breast. Of importance is that, in addition to MEC, the patient had a wide area of scar tissue secondary to a burn that completely occupied the left bottom quadrant of the abdomen and retracted the left nipple up to the left upper quadrant. Fine needle aspiration biopsy was negative, and a lumpectomy was performed. Because the pathology results were consistent with MEC, modified radical mastectomy with subsequent adjuvant chemotherapy and radiotherapy was performed. The patient remained disease-free for 12 months after the treatment. In addition to a discussion of this case, we performed a review of the clinicopathological characteristics of 30 cases with breast MEC reported in the English language literature between 1979 and 2010. Conclusions: MEC of the breast is a rarely seen tumor, and this is the first report of MEC in a breast affected by burn scars.

\author{
Schlüsselwörter \\ Mukoepidermoides Karzinom · Brust · Verbrennung
}

\section{Zusammenfassung}

Hintergrund: Mukoepidermoide Karzinome (MEC) treten primär in den Speicheldrüsen auf und betreffen nur selten die Brust. MEC entstehen gewöhnlich aus dem Plattenepithel und mukusproduzierenden Zellen. Das histologische Stadium ist ein wichtiger Prognosefaktor. Fallbericht: Wir berichten von einer 69-jährigen Patientin, die mit einer schmerzhaften Umfangsvermehrung in der linken Brust vorstellig wurde. Von Bedeutung ist, dass die Patientin neben einem MEC auch großflächiges Narbengewebe infolge einer Verbrennung aufwies, welches den linken unteren Quadranten des Abdomens komplett bedeckte und eine Retraktion der linken Brustwarze in den linken oberen Quadranten bewirkte. Nachdem die Feinnadelaspirationsbiopsie ein negatives Ergebnis zeigte, wurde eine Lumpektomie durchgeführt. Da das Ergebnis der pathologischen Untersuchung auf ein MEC hindeutete, wurde eine modifizierte radikale Mastektomie mit anschließender adjuvanter Chemotherapie und Radiotherapie durchgeführt. Die Patientin blieb nach der Behandlung 12 Monate lang krankheitsfrei. Neben der Diskussion des vorliegenden Falles wird eine Übersicht über die klinikopathologischen Charakteristika von 30 Fällen von MEC der Brust in der englischsprachigen Literatur (1979-2010) gegeben. Schlussfolgerungen: MEC der Brust ist eine seltene Tumorform, und dies ist der erste Bericht von einem MEC in einer von Brandnarben betroffenen Brust.

\section{KARGER \\ Fax +497614520714 \\ Information@Karger.de}

www.karger.com (c) 2011 S. Karger GmbH, Freiburg

1661-3791/11/0064-0293\$38.00/0

Accessible online at:

www.karger.com/brc 


\section{Introduction}

Mucoepidermoid carcinoma (MEC) is a type of cancer that is usually seen in the major and minor salivary glands, and may also occur in the breast, thyroid, and lacrimal glands $[1,2]$. Breast MEC, a rare type of breast cancer, shows morphological and immunohistochemical features similar to those of salivary glands [3]. The cancer usually develops from basaloid (squamous), intermediate, epidermoid, and mucinous cells. The histological grading in MEC is an important prognostic factor in invasive breast cancer, and is carried out using the grading methods of Auclair et al. [4] and Elston et al. [5], the latter of which is more commonly used for MEC of the breast. Tumors with high grades have a poorer prognosis, while those with lower grades have a better prognosis. Symptoms vary according to the organ in which the tumor resides. Treatment choices include excision, radiotherapy, and chemotherapy. Patchefsky et al. [6, 7] first reported MEC of the breast in 1979. Since then, 30 cases of breast MEC have been reported in the literature, all of them case reports. In this study, we present a patient with a mass of the left breast; the breast papilla reached up to the left upper quadrant of the abdomen due to a wide burn scar, thereby causing deformation of the breast tissue. A review of 30 cases reported in the English language literature is also presented.

\section{Case Report}

A 69-year-old female patient presented to our clinic with complaints of a mass and pain of the left breast. The physical examination revealed that the mass she had first noticed 1 year ago had grown over time and was now measuring $8 \times 10 \mathrm{~cm}$, completely occupying the left breast. In addi-

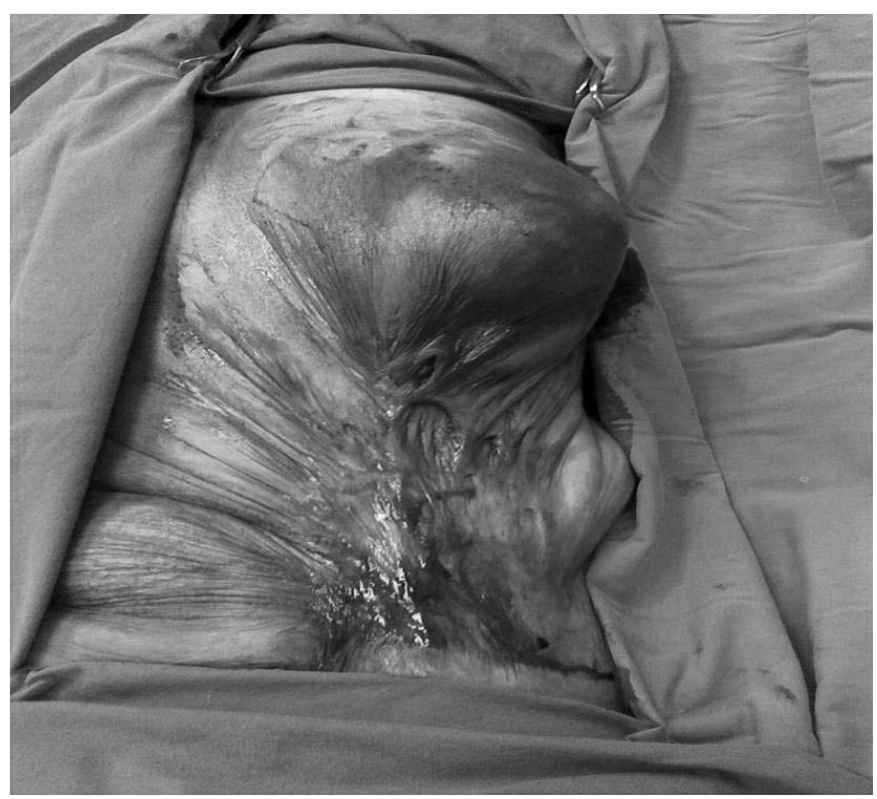

Fig. 1. Postoperative view of the anterior aspect of the left anterior abdominal wall and mass located in the left breast tissue affected by the previous burn.

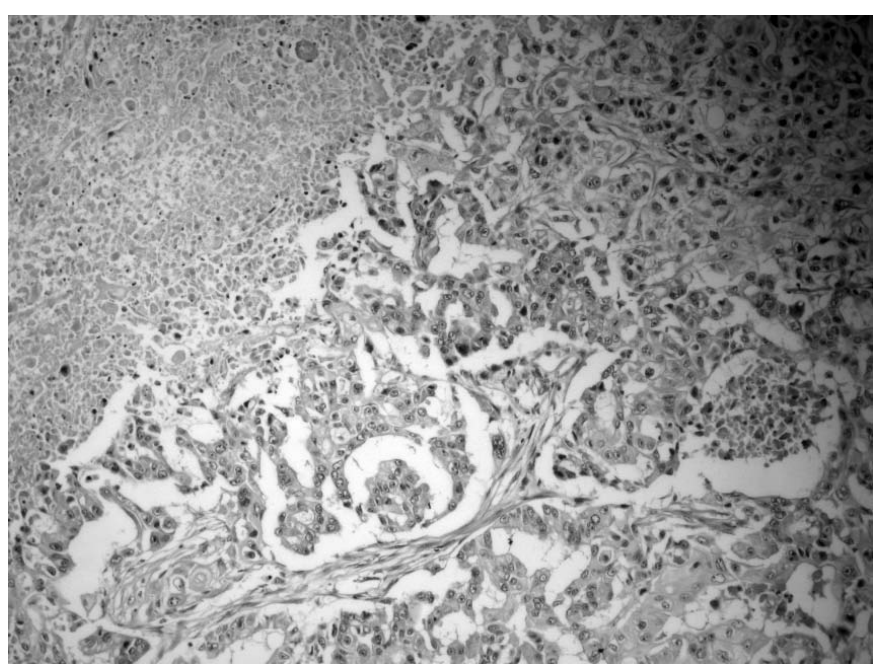

Fig. 2. Infiltrative solid tumor containing cystic spaces filled with mucus, necrosis, and squamous cells with individual cell keratinization $(\mathrm{H}$ and $\mathrm{E}$ stain, $\times 100)$.

tion, scar tissue from a heat burn she had suffered in childhood was completely retracting the left abdominal side. Secondary to this scar tissue, the left breast papilla was retracted to the left upper quadrant of the abdomen, and the anatomical structure of the breast tissue was distorted (fig. 1). Palpation revealed that the breast mass was mobile, stiff, and uniformly bounded. In the axillary examination, lymph nodes, the largest of which was $2 \mathrm{~cm}$, were detected. The physical examination of the right breast was normal. Among the tumor markers, cancer antigen 15-3 was $28.17 \mathrm{U} / \mathrm{ml}(0-25 \mathrm{U} / \mathrm{ml})$. Bilateral breast ultrasonography (USG) showed that the left breast was deformed secondary to the previous burn, as well as the presence of a smoothly contoured, hypoechoic lesion containing both cystic and solid zones and occupying virtually the entire breast. Enlarged lymph nodes, the largest of which was $19 \times 11 \mathrm{~mm}$, were detected in the left axillary region, while no cystic or solid lesion was detected in the right breast. On subsequent bilateral mammography, the craniocaudal view could not be taken through the left breast because it was stuck to the chest wall as a result of the previous burn. On the mediolateral oblique test of the left breast, the breast density was increased because of edema and inflammation, and the fibroglandular tissue density was increased in the retroareolar area. By fine needle aspiration biopsy (FNAB), approximately $150-200 \mathrm{ml}$ of a particle-containing, dark hemorrhagic liquid was aspirated. Subsequent to aspiration, an encapsulated mass, in which palpable solid areas were present, remained. FNAB was taken from this mass using a different syringe. Because the FNAB result was negative, lumpectomy was performed, including the skin covering the mass.

In the perioperative exploration, the mass was revealed to be encapsulated and isolated from surrounding tissues. The specimen, the surgical limits of which were intact, was reported as consistent with MEC; therefore, the patient underwent modified radical mastectomy. No pathological signs were observed on thoracic computed tomography or abdominal USG, which were performed before the scheduled operation. With an ASA-II risk score, the patient underwent a left modified radical mastectomy that included some of the scar tissue. Histological examination showed an infiltrative solid tumor containing cystic spaces filled with mucus, hemorrhagic material, and necrotic debris (fig. 2). The tumor cells were epithelial in nature and included multiple cell types such as squamous, mucous, and cuboidal intermediate cells. Squamous cells with individual cell keratinization (fig. 3) and mucous cells lining some of the cystic spaces were observed. Immunohistochemically, MUC-1 was positive in the mucinous tumoral areas; however, estrogen and progesterone 


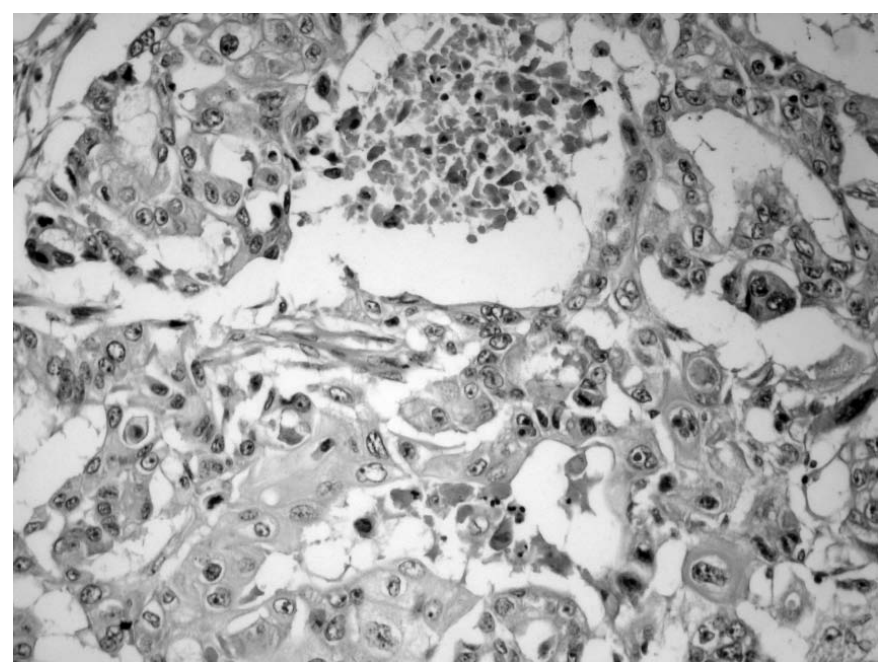

Fig. 3. Tumor cells with individual cell keratinization can be seen $(\mathrm{H}$ and E stain, $\times 200)$.

receptors and Her-2/neu overexpression were negative in all components of the tumor (fig. 4). In light of the data obtained, the tumor was considered as T3N0M0 (stage IIB) with respect to TNM staging and as triplenegative hormonally. The patient was given adjuvant chemotherapy according to the guideline of the National Comprehensive Cancer Network (NCCN). She received 6 courses of a doxorubicin and cyclophosphamide chemotherapy protocol. Despite the lack of lymph node metastasis, she was also given adjuvant radiotherapy (a total of 45 Gy in 25 fraction) since the tumor showed mucoepidermoid features and the tumor size was $>5 \mathrm{~cm}$. Adjuvant hormonal treatment was not tried because the tumor was hormone receptor-negative. 12 months later, the patient remained alive, without any disease.

\section{Discussion}

MEC is a malignant epithelial tumor that Foote and Frazell [8] reported for the first time as a salivary gland tumor; it is one of the common histological types of salivary gland tumor. MEC represents approximately $30 \%$ of malignant tumors originating in the major and minor salivary glands [1]. Other than in the salivary glands, MEC is seen in the nasal cavity, esophagus, and bronchi, all of which develop from the embryonic ectoderm. Less frequently, it is seen in the pancreas, lacrimal glands, intestinal mucosa, and breast tissue.

Because both mammary and salivary glands share certain structural features, it is not surprising that salivary gland-like tumors can also be found in the breast [9]. Salivary gland-like tumors of the breast have been divided into tumors with myoepithelial differentiation (e.g., pleomorphic adenoma) and tumors devoid of myoepithelial differentiation (e.g., MEC) $[3,7,9]$. MEC of the breast, a variant of breast carcinoma, is a rare primary tumor, accounting for an incidence of approximately $0.2-0.3 \%[7,10,11]$.

The English language literature published between 1979 and November 2010 in the PubMed and Google Scholar data-

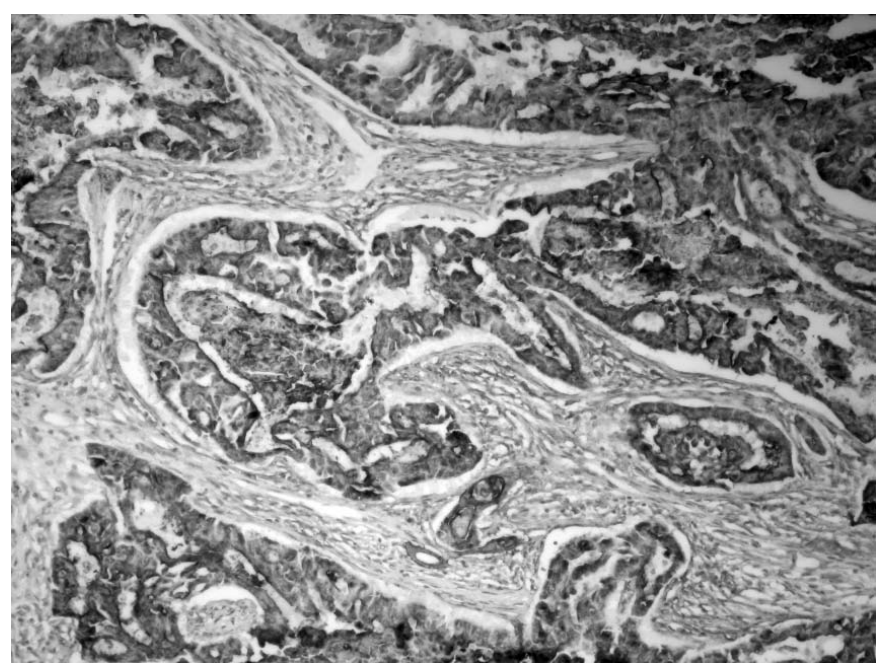

Fig. 4. MUC-1 positivity in the mucinous tumoral areas (immunoperoxidase, $\times 200)$.

bases was reviewed, and 19 articles concerning 30 patients with primary MEC of the breast were explored. Thirty patients were female, with ages ranging from 27 to 80 years (median, $55.2 \pm 14.1$ years). Thirteen patients had high-grade MEC, 13 had low-grade MEC, 2 had intermediate MEC, and the remaining 2 were not stated. Nine patients were positive and 13 were negative for lymph node metastasis in the axillary region. The remaining 8 patients had no information regarding axillary metastasis. Table 1 summarizes the references and publication years of the studies, as well as age, sex, tumor grade, tumor site, tumor size, distant and lymph node metastasis, surgical approach, follow-up, and outcome of those 30 patients, and also includes the current case [1-3, 6-22].

In the grading of breast MEC, the method of Auclair et al. [4] was used to grade salivary gland MEC, and that of Elston et al. [5], which is more commonly used for MEC of the breast, was used for breast MEC. The parameters for grading included the ratio of cystic components, the existence of neural invasion, the presence of necrosis, the mitotic ratio, and the nuclear grade $[1,23]$. Three forms of MEC have been generally accepted: low-grade, intermediate, and high-grade lesions. Although the boundaries of low-grade tumors are prominent, cystic lesions containing mucin are sometimes observed. Epidermoid or mucin-secreting cells are usually present in the centers of lesions. This group usually has a favorable prognosis with rare axillary metastasis. Focal squamous differentiation, undifferentiation, the existence of intermediate cells and neural invasion, and an increased rate of necrosis are usually indicators of an aggressive course for tumors. Axillary and distant organ metastases are particularly observed in these patient groups [9].

Histopathologically, MEC of the breast is composed of basaloid, intermediate, epidermoid, and mucinous cells. Basaloid cells are small in size and oval in shape; they have round- 
Table 1. A summary of 30 cases of mucoepidermoid carcinoma of the breast reported in the English language literature from 1979 to 2010

\begin{tabular}{|c|c|c|c|c|c|c|c|c|c|c|c|c|}
\hline Author [ref.] & Year & $\begin{array}{l}\text { Age, } \\
\text { years }\end{array}$ & Sex & Grade & Site & $\begin{array}{l}\text { Size, } \\
\mathrm{cm}\end{array}$ & $\begin{array}{l}\text { Distant } \\
\text { metastasis }\end{array}$ & $\begin{array}{l}\text { Lymphatic } \\
\text { metastasis }^{\mathrm{a}}\end{array}$ & $\begin{array}{l}\text { Surgical } \\
\text { approach }\end{array}$ & $\begin{array}{l}\text { Medical } \\
\text { approach }\end{array}$ & $\begin{array}{l}\text { Follow- } \\
\text { up, } \\
\text { months }\end{array}$ & Status \\
\hline Camelo-Piragua et al. [7] & 2009 & 49 & $\mathrm{~F}$ & IG & $\mathrm{R}$ & 4.0 & no & $1 /(3)$ & MRM & $\mathrm{CT}$ & 12 & alive \\
\hline \multirow{2}{*}{ Hornychova et al. [9] } & 2007 & 63 & $\mathrm{~F}$ & $\mathrm{H}$ & $\mathrm{R}$ & 1.8 & no & $0 /(17)$ & $\mathrm{SM}+\mathrm{LND}$ & $\mathrm{CT}+\mathrm{RT}$ & 18 & alive \\
\hline & & 30 & $\mathrm{~F}$ & Lo & $\mathrm{L}$ & 8.0 & no & $0 /(\mathrm{NA})$ & MRM & $\mathrm{CT}+\mathrm{RT}$ & 60 & alive \\
\hline Horii et al. [1] & 2006 & 54 & $\mathrm{~F}$ & Lo & $\mathrm{L}$ & 2.5 & no & $0 /(\mathrm{NA})$ & MRM & $\mathrm{CT}$ & 36 & alive \\
\hline Gomez-Aracil et al. [11] & 2006 & 69 & $\mathrm{~F}$ & $\mathrm{H}$ & $\mathrm{R}$ & 6.0 & no & $24 /(28)$ & MRM & $\mathrm{CT}$ & 54 & alive \\
\hline \multirow[t]{5}{*}{ Tommaso et al. [3] } & 2004 & 80 & $\mathrm{~F}$ & Lo & $\mathrm{L}$ & 0.5 & no & NS & excision & NS & 5 & alive \\
\hline & & 29 & $\mathrm{~F}$ & Lo & $\mathrm{L}$ & 0.8 & no & NS & excision & NS & 90 & alive \\
\hline & & 54 & $\mathrm{~F}$ & Lo & $\mathrm{L}$ & 1.5 & no & NS & $\mathrm{Q}+\mathrm{LND}$ & NS & 13 & alive \\
\hline & & 36 & $\mathrm{~F}$ & $\mathrm{H}$ & $\mathrm{L}$ & 1.1 & no & NS & $\mathrm{Q}+\mathrm{LND}$ & NS & 18 & alive \\
\hline & & 55 & $\mathrm{~F}$ & IG & $\mathrm{L}$ & 0.6 & no & NS & $\mathrm{Q}+\mathrm{LND}$ & NS & 3 & alive \\
\hline Tjalma et al. [13] & 2002 & 58 & $\mathrm{~F}$ & Lo & $\mathrm{R}$ & 3.5 & yes & $1 /(17)$ & $\mathrm{RM}$ & NS & 156 & alive \\
\hline Berry et al. [2] & 1998 & 51 & $\mathrm{~F}$ & $\mathrm{H}$ & $\mathrm{L}$ & 3.5 & no & $0 /(\mathrm{NA})$ & $\mathrm{RM}$ & NS & NS & NS \\
\hline Markopoulos et al. [14] & 1998 & 40 & $\mathrm{~F}$ & $\mathrm{H}$ & $\mathrm{R}$ & 2.0 & no & $0 /(\mathrm{NA})$ & $\mathrm{WE}+\mathrm{LND}$ & NS & 60 & alive \\
\hline Chang et al. [15] & 1998 & 54 & $\mathrm{~F}$ & $\mathrm{H}$ & $\mathrm{L}$ & 4.5 & no & $0 /(9)$ & MRM & $\mathrm{CT}$ & 48 & alive \\
\hline Pettinato et al. [17] & 1989 & 72 & $\mathrm{~F}$ & $\mathrm{H}$ & $\mathrm{R}$ & 7.0 & yes & $16 /(19)$ & MRM & $\mathrm{CT}$ & 10 & DOD \\
\hline \multirow[t]{2}{*}{ Hanna and Kahn [12] } & 1985 & 51 & $\mathrm{~F}$ & NS & $\mathrm{L}$ & 2.0 & no & $0 /(\mathrm{NA})$ & MRM & none & 8 & alive \\
\hline & & 31 & $\mathrm{~F}$ & NS & NA & NA & no & $2 /(18)$ & MRM & $\mathrm{CT}$ & 14 & alive \\
\hline Hastrup and Sehested [18] & 1985 & 59 & $\mathrm{~F}$ & $\mathrm{H}$ & $\mathrm{L}$ & 1.0 & yes & $0 /(4)$ & MRM & $\mathrm{CT}+\mathrm{RT}$ & 25 & DOD \\
\hline Leong and Williams [19] & 1985 & 57 & $\mathrm{~F}$ & $\mathrm{H}$ & $\mathrm{L}$ & 3.5 & yes & $0 /(20)$ & SM & none & 7 & DOD \\
\hline Ratanarapee et al. [20] & 1983 & 27 & $\mathrm{~F}$ & $\mathrm{H}$ & NA & NA & yes & $6 /(15)$ & NA & NA & 14 & DOD \\
\hline \multirow[t]{5}{*}{ Fisher et al. [10] } & 1983 & 65 & $\mathrm{~F}$ & Lo & $\mathrm{R}$ & 2.0 & no & NS & Lump & NS & 60 & alive \\
\hline & & 71 & $\mathrm{~F}$ & Lo & $\mathrm{L}$ & 2.0 & no & $0 /(19)$ & MRM & NS & 48 & alive \\
\hline & & 57 & $\mathrm{~F}$ & Lo & $\mathrm{R}$ & 2.5 & no & $0 /(11)$ & MRM & NS & 120 & alive \\
\hline & & 49 & $\mathrm{~F}$ & Lo & $\mathrm{R}$ & 3.7 & no & $0 /(13)$ & RM & NS & 108 & alive \\
\hline & & 60 & $\mathrm{~F}$ & Lo & $\mathrm{L}$ & 4.0 & no & NS & SM & NS & 48 & $\mathrm{XX}$ \\
\hline Kovi et al. [21] & 1981 & 46 & $\mathrm{~F}$ & $\mathrm{H}$ & $\mathrm{L}$ & 11.0 & NS & $17 /(19)$ & MRM & NS & NS & NS \\
\hline \multirow[t]{2}{*}{ Patchefsky et al. [6] } & 1979 & 66 & $\mathrm{~F}$ & Lo & $\mathrm{R}$ & 1.3 & no & $0 /(20)$ & $\mathrm{RM}$ & NS & 94 & XX \\
\hline & & 70 & $\mathrm{~F}$ & Lo & $\mathrm{R}$ & 5.0 & no & NS & $\mathrm{Q}$ & NS & 10 & alive \\
\hline Present case & & 69 & $\mathrm{~F}$ & $\mathrm{H}$ & $\mathrm{L}$ & 10.0 & no & $0 /(12)$ & MRM & $\mathrm{CT}+\mathrm{RT}$ & 12 & alive \\
\hline
\end{tabular}

$\mathrm{F}=$ Female; $\mathrm{IG}=$ intermediate grade; $\mathrm{H}=$ high grade; Lo = low grade; $\mathrm{R}=$ right; $\mathrm{L}=$ left; $\mathrm{NS}=$ non-stated; NA = not applicable;

$\mathrm{MRM}=$ modified radical mastectomy; $\mathrm{SM}=$ simple mastectomy; $\mathrm{LND}=$ lymph node dissection; $\mathrm{Q}=\mathrm{quadrantectomy} ; \mathrm{RM}=$ radical mastectomy;

Lump = lumpectomy; CT = chemotherapy; RT = radiotherapy; DOD = died of disease; XX = died from other causes.

a Involved nodes (dissected nodes).

to-oval nuclei with dark, coarse chromatin, and are numerous at the periphery of neoplastic nests. Intermediate cells are larger than basaloid cells and have eosinophilic cytoplasm, oval nuclei, and small nucleoli [12]. Epidermoid cells are larger than intermediate cells and have polygonal shapes, eosinophilic cytoplasm, and round-to-oval nuclei. Immunohistochemically, MEC stains positive for cytokeratin (CK)-7, CK-5/6, CK-14, mucins (MUC), p53, vascular endothelial growth factor (VEGF), and epidermal growth factor receptor (EGFR). Tumor cells do not express hormonal receptors (neither estrogen nor progesterone), nor HER-2/neu protein.

A differential diagnosis list should be formulated in cases with metastasis from salivary gland MEC and with other types of primary carcinoma of the breast, such as squamous cell, lobular, mucinous or colloid, metaplastic, and adenosquamous carcinoma [11]. Treatment of MEC varies according to tumor location and grade. Treatment choices include surgical excision, chemotherapy, and radiotherapy. There is very little data available in the literature regarding breast MEC, and most reports are case report. Hence, it is hard to make a clear comment on the medical treatment of these patients. As a result of our literature search, we found that 6 breast MEC patients had been given chemotherapy [1, 7, 11, 12, 15, 17], while 3 had been given radiotherapy in addition to chemotherapy $[9,18]$. In 2 cases, no therapy other than surgery was applied, whereas no clear comment was made on the therapy of other cases. In the present case, chemoradiotherapy was performed by a medical and radiation oncologist after pathological observation of the specimen which was obtained by modified radical mastectomy.

The prognosis of MEC of the salivary gland depends on the degree of differentiation, completeness of excision, and clinical staging. MEC of the breast is a rare entity, and its prognostic features are not well established [7]. Five patients who had high-grade MEC died of the disease. All patients who died of the disease had distant metastasis. On the other hand, patients with high-grade tumors but without distant metastasis were all alive at follow-up (18-60 months). None of the patients with low-grade or intermediate breast MEC died of the disease. 
In conclusion, MEC of the breast is a rarely seen tumor and frequently has similarities with tumors of other tissues of ectodermal origin. Notably, dysplastic changes together with epidermoid mucin islets in areas close to the burn scar were observed in MEC of the breast in the present case, which is extremely rare. Considering that malignant transformation might develop from scar tissue over time, we can assume that the malignant transformation of the burn scar in our case could have played a trigger role in the development of MEC in the breast.

\section{Author Contributions}

Basbug M, Arikanoglu Z, and Akbulut S performed the surgical procedure; Firat U and Sogutcu N performed the histopathological examination. Basbug $\mathrm{M}$ contributed to writing the article and review of the literature, as well as undertaking a comprehensive literature search; Basbug M, Akbulut $\mathrm{S}$ and Kucukoner M contributed to the design and preparation of the manuscript.

\section{Disclosure Statement}

The authors have no conflicts of interest or competing financial interests with regards to this manuscript.

\section{References}

1 Horii R, Akiyama F, Ikenaga M: Muco-epidermoid carcinoma of the breast. Pathol Int 2006;56:549 553.

2 Berry MG, Caldwell C, Carpenter R: Mucoepidermoid carcinoma of the breast: a case report and review of the literature. Eur J Surg Oncol 1998:24.1:78-80.

3 Tommaso LD, Foschini MP, Ragazzini T: Mucoepidermoid carcinoma of the breast. Virchows Arch 2004:444:13-19.

4 Auclair PL, Goode RK, Ellis GL: Mucoepidermoid carcinoma of intraoral salivary glands. Cancer 1992;69:2021-2030.

5 Elston CW, Ellis IO: Pathological prognostic factors in breast cancer. The value of histological grade in breast cancer: experience from a large study with long-term follow-up. Histopathology 1991;19:403-410.

6 Patchefsky AS, Frauenhoffer CM, Krall RA, Cooper HS: Low grade mucoepidermoid carcinoma of the breast. Arch Pathol Lab Med 1979;103:196-198.

7 Camelo-Piragua SI, Habib C, Kanumuri P, Lago CE, Mason HS, Otis CN: Mucoepidermoid carcinoma of the breast shares cytogenetic abnormality with mucoepidermoid carcinoma of the salivary gland: a case report with molecular analysis and review of the literature. Hum Pathol 2009;40:887892.
8 Foote FW, Frazell EL: Tumors of the Major Salivary Glands. Washington, DC, Armed Forces Institute of Pathology, 1954

9 Hornychová H, Ryska A, Betlach J: Mucoepidermoid carcinoma of the breast. Neoplasma 2007;54:168-172.

10 Fisher ER, Gregorio RM, Palekar AS: Mucoepidermoid and squamous cell carcinomas of breast with reference to squamous metaplasia and giant cell tumours. Am J Surg Pathol 1983;7:15-27.

11 Gomez-Aracil V, Mayayo Artal E, Azua-Romeo J, Mayayo Alvira R, Azúa-Blanco J, Arraiza Goicoechea A: Fine needle aspiration cytology of high grade mucoepidermoid carcinoma of the breast: a case report. Acta Cytol 2006;50:344-348.

12 Hanna W, Kahn HJ: Ultrastructural and immunohistochemical characteristics of mucoepidermoid carcinoma of the breast. Hum Pathol 1985;16:941946.

13 Tjalma WA, Verslegers IO, De Loecker PA, Van Marck EA: Low and high grade mucoepidermoid carcinomas of the breast. Eur J Gynaecol Oncol 2002;23:423-425.

14 Markopoulos C, Gogas H, Livaditou A, Floros D: Mucoepidermoid carcinoma of the breast. Eur J Gynaecol Oncol 1998;19:291-293.

15 Chang LC, Lee N, Lee CT, Huang JS: High-grade mucoepidermoid carcinoma of the breast: case report. Changgeng Yi Xue Za Zhi 1998;21:352-357.
16 Luchtrath H, Moll R: Mucoepidermoid mammary carcinoma. Immunohistochemical and biochemical analyses of intermediate filaments. Virchows Arch A Pathol Anat Histopathol 1989;416:105-113.

17 Pettinato G, Insabato L, De Chiara A, Manco A, Petrella G: High-grade mucoepidermoid carcinoma of the breast. Fine needle aspiration cytology and clinicopathologic study of a case. Acta Cytol 1989;33:195-200.

18 Hastrup N, Sehested M: High-grade mucoepidermoid carcinoma of the breast. Histopathology 1985;9:887-892.

19 Leong AS, Williams JA: Mucoepidermoid carcinoma of the breast: high grade variant. Pathology 1985;17:516-521.

20 Ratanarapee S, Prinyar-Nussorn N, Chantarakul N, Pacharee P: High-grade mucoepidermoid carcinoma of the breast. A case report. J Med Assoc Thai 1983;66:642-648.

21 Kovi J, Duong HD, Leffall LS Jr: High-grade mucoepidermoid carcinoma of the breast. Arch Pathol Lab Med 1981;105:612-614.

22 Terzi A, Saglam A, Uner A: A 79 year-old woman with a mass in the right breast. Turk $\mathrm{J}$ Cancer 2004;34:38-39.

23 Ellis GL, Auclair PL: Tumors of the salivary glands; in Ellis GL, Auclair PL (eds): Atlas of Tumor Pathology, 3rd series, fascicle 17. Washington, DC, Armed Forces Institute of Pathology, 1996, pp. 155-175. 